\title{
Aerobic Rice Cultivation System: Eco-Friendly and Water Saving Technology under Changed Climate
}

\author{
Jana $\mathrm{K}^{1 *}$, Karmakar $\mathbf{R}^{1}$, Banerjee $\mathrm{S}^{2}$, Sana $\mathbf{M}^{2}$, Goswami $\mathrm{S}^{1}$ and Puste $\mathrm{AM}^{2}$ \\ ${ }^{1}$ Directorate of Research, Bidhan Chandra Krishi Viswavidyalaya, India \\ ${ }^{2}$ Department of Agronomy, Bidhan Chandra Krishi Viswavidyalaya, Indi ${ }^{a}$
}

Submission: September 21, 2017; Published: January 09, 2018

"Corresponding author: Directorate of Research, Bidhan Chandra Krishi Viswavidyalaya, Kalyani - 741235, Nadia, West Bengal, India, Email: kjanarrs@gmail.com

\begin{abstract}
Millions of peoples depend on rice to maintain their livelihoods and for this reason rice is called life. Water is becoming scare for agriculture purposes at present situation. Rice is a semi-aquatic crop among the cereals and its cultivation is a water intensive enterprise. About 4000-5000 litres of water is consumed for production of $1 \mathrm{~kg}$ rice. There is a need to develop an alternative system of rice cultivation to save the water and other inputs. Aerobic rice system is a new way of growing rice that needs less water than low land rice. It is grown like an upland crop in soil that is not puddled, non-flooded or saturated. The soil is therefore 'aerobic' or with oxygen through the growing season. Aerobic rice system is eco-friendly approach and safe for the environment.
\end{abstract}

Keywords: Aerobic rice system; Changed climate; Eco-friendly and water saving technology

\section{Introduction}

Rice is an important staple food crop of the world. Rice is life. Millions of people in Asia depended on rice to survive. Annual rice production should be increased to meet the demand of ever growing population. This increase in production has to come despite the declining resources like land and water, which is a daunting task. Water is becoming scare for agriculture at present situation. Rice consumes more than $50 \%$ of the water used for irrigation in Asia Barker et al. [1]. Per capita water availability has dwindled from $5300 \mathrm{~m} 3$ year- 1 in 1953 to $2500 \mathrm{~m} 3$ year- 1 in 1990 and expected to further shrink to $1500 \mathrm{~m} 3$ year-1 by 2025 signifying considerable reduction in water availability.

About 4000-5000 litres of water is consumed for production of one $\mathrm{kg}$ rice. Rice cultivation is a water intensive enterprise. However, lowland rice fields have relatively high water requirements and their sustainability is threatened by increasing water shortages Bouman \& Tuong [2]. Water shortages are going to become a major issue in the future. Hence, it is imperative to develop technology to increase the water use efficiency in rice cultivation. It is grown like an upland crop in soil that is not puddled, non-flooded or saturated. It is a sustainable rice production methodology for immediate future to address water scarcity and environmental safety arising due to global warming Jana [3].

\section{Definition of 'Aerobic Rice' cultivation system}

Aerobic rice cultivation system is the method of cultivation, where the rice crop is established by direct seeding (dry or water-soaked seed) in non-puddle field and un-flooded field condition. The usual way of planting aerobic rice is the same as we would plant the other cereal crops like wheat or maize-by direct seeding. It is the most promising approaches for saving water and labour.

\section{Why 'Aerobic' term is used}

It is grown like an upland crop in soil that is unpuddle, non-flooded or saturated. The soil is therefore 'aerobic' or with oxygen through the growing season, as compared to traditional flooded fields, which are 'anaerobic'.

\section{Basic Principles of this System}

'Aerobic rice' cultivation system is the methodology, which involves a set of practices for seed treatment, plant, soil, weed, 
water and nutrient management. The basic practices of this system are:

a. Direct seeding of treated seed in non-puddle and non flooded field

b. It can be rain fed or fully irrigated or supplementary irrigated

c. Maintain water at just soil saturation level (aerobic i.e. with oxygen)

d. Effective and timely weed control is crucial for success of this system

e. Row to row spacing should be adopted at 20 or $25 \mathrm{~cm}$ with continuous sowing

f. Use of best nutrient management practices along with use of FYM/compost/vermicompost etc.

\section{Significance of Aerobic Rice System}

Aerobic rice is grown like any other crops like maize or sorghum on dry soils with surface irrigations provided when necessary with intensive agronomic practices. Compared with flooded lowland rice, aerobic rice requires 30-50\% less water Bouman et al. [4]. Supplementary irrigation is applied in aerobic rice system of cultivation as and when required and can be supplied in the same way as to any upland cereals crops like maize, wheat Bouman et al. [4], Wang et al. [5]. Aerobic rice is a water and labour saving technology for water-shortage environments.

It is a modern production system with favourable soils and adapted, potentiality high-yielding varieties that are direct dry seeded. Aerobic rice is not ponded and irrigated similar to other upland cereal crop and is suitable for water scare environments, and it can stand being periodically flooded Xiaoguange et al. [6].

Aerobic Rice Cultivation System: Produce Low Methane (CH4)

The process of methanogenesis, which is emission of methane through decomposition of organic, is prevented as soil bacteria decompose organic matter under aerobic (with oxygen) condition. Methane is produced by anaerobic (without oxygen) decomposition of organic matter in the soil under flooded rice cultivation. Vial, 2007 reported that approximate $50 \%$ reduction in $\mathrm{CH} 4$ emission under aerobic rice system from some trials, were conducted at IRRI. So, we can say that the aerobic rice system is eco-friendly approach and safe for the environment.

\section{Suitable Areas for Growing Aerobic Rice}

a. Upland areas and mid-upland where land is flat

b. Upper slopes or terraces in undulating areas

c. Deep soils, which can supply water to the crop between rainfall events/irrigation Maiti \& Banerjee [7].

\section{Package of Practices for Aerobic Rice Cultivation}

Aerobic rice cultivation is a sustainable rice production methodology for immediate future. Research on aerobic rice regarding variety development, suitable agro-techniques and different management practices are going on.

\section{Selection of Suitable Field}

a. Select well leveled fields with good drainage facility.

b. Avoid saline/alkaline and inundated low lying fields.

\section{Selection of variety}

Select most of the popular high yielding varieties (duration: 115-125 days) for the region can be successfully grown under aerobic rice cultivation. In a pioneering effort in March, 2007, India officially released its first drought tolerant aerobic rice variety MAS 946-1 followed by MAS 26 (2008) at University of Agricultural Science, Bangalore. Yields were at par with irrigated puddled rice with an average of 5.5-6tha-1 with 60 percent less water requirement as reported by Hittalmani [8]. These two first varieties are popularized for aerobic cultivation in the country.

\section{Puspa (IET 17509)}

It is an early duration high yielding rice variety released by the 'State Variety Release Committee, West Bengal' in 2011 for cultivation in upland areas of West Bengal, India. It was developed at Rice Research Station, Bankura, West Bengal, India. Before release as 'Puspa', it had completed three years (20032005) of National Testing in the designation of CNB 1259-5-21 and IET No. 17509 . It gave 10.43 to $22.80 \%$ more yield than the National check Annada at National level. Puspa is a nonlodging, non-shattering, drought tolerant early variety with $50 \%$ flowering in 79days and seed to seed 105 days during kharif.

Its average yield ranged from 4500-5000kgha-1 and productivity $8216 \mathrm{~kg}$ ha-1. It is resistant to leaf blast, sheath blight, sheath rot, bacterial blight, brown spot and BPH and tolerant to leaf folder and stem borer. Its grain type is short bold and it has 96.2ppm iron in whole grain Mallick et al. [9]. Short duration rice varieties, like Puspa (IET-17509) and Annada are suitable for aerobic rice system in un-puddled situation during boro season under red and laterite zone of West Bengal, India Jana [10].

8.3.1.Seed rate: $25-30 \mathrm{~kg}$ seed per ha.

8.3.2.Seed treatment: Treat the seeds with carbendazim @2g/kg seed.

\section{Main Land Preparation}

At the onset of monsoon with little showers or with the application of irrigation water if available, field preparation is completed. Initially plough the field in dry condition 2-3 times and pulverize. Apply well decomposed cow dung/FYM/compost @ 4-5t acre- 1 before ploughing operation and incorporate it into the soil thoroughly. 


\section{Spacing and sowing}

Row to row distance is 20 or $25 \mathrm{~cm}$ with continuous sowing is to be done. The usual way of planting aerobic rice is the same as how we would plant wheat or maize or sorghum by dry direct seeding. Line sowing is done during ideal moisture content of soil.

\section{Irrigation water management}

Aerobic rice system can be rain fed or fully irrigated or supplementary irrigated. It can be also grown entirely on rainfall in wet season with a well distributed rain. Water management is done to keep soil moist alternate wetting and drying. Maintain water at just soil saturation level by intermittent light irrigation coinciding with appearance of hair line cracks or when see the visual condition (sign or symptoms) of the rice plant. Aerobic rice cultivation can reduce the irrigation by about 40-50 percent when compared to transplanted rice.

Irrigation should be apply according to critical physiological growth stages of rice crop, viz. 1 DAS (or pre sowing), tillering, panicle initiation (PI), flowering and grain filling stages, respectively for obtaining good grain yield particularly during rabi season/boro as reported by Jana [10]. But, it needs further research work in depth.

\section{Weed management}

Weed population is very high in aerobic rice culture due to non-flooded condition as compared to conventional method of rice cultivation (flooded condition). That's why weed poses a bigger threat in aerobic direct seeded rice system. Preemergence application of pendimethalin (PE) @1.0kgha-1 at 1-2 days after sowing should be done. 2, 4-D Na salt @ 0.80kgha-1 at 25-30 days after sowing is applied. Two mechanical weeding or two hand weeding is done at 40 and 60 days after sowing (DAS). Pre-emergence application of pendimethalin + Rice : Dhaincha (1:1) + one (1) hand weeding or 2, 4-D Na salt application recorded lower weed biomass at 25 DAS of Rice under aerobic condition during kharif season. At 55 DAS, with or with-out preemergence application of pendimethalin, 2 mechanical weedings controlled weed population and reduced weed biomass. Higher weed biomass was observed with higher nitrogen application at 55 DAS Jana [11].

\section{Nutrient management}

Well rotten cow dung manure/F.Y.M/compost @5t acre- 1 is applied at time of final land preparation and mixed it with the soil thoroughly. Zinc sulphate (ZnSo4) is applied @20-25kgha-1, if $\mathrm{Zn}$ is deficient in soil for proper soil health management. N, P205, K20 @100-125, 60-40, 60-40kgha-1 is applied. Half dose of nitrogen, full dose of phosphorus, $75 \%$ of potash and full dose of zinc (20-25kg ZnSo4/ha) as basal and remaining dose of $\mathrm{N}$ in two splits $(25 \% \mathrm{~N}$ at active tillering and $25 \% \mathrm{~N}$ along with $25 \%$ potash at panicle initiation) are applied. It needs further research work in depth. Incorporation of Glyricidia (leaf and twigs) as green manure @3tha-1at 20 DBS (days before sowing) was done Jana [12].

\section{Performance of aerobic rice system regarding yield}

Aerobic rice technology was first introduced in the Philippines by the International Rice Research Institute (IRRI) approximately ten years ago. In the Philippines, wet season yields were 4 to more than 5 t ha-1. In the dry season, however, the yields ranged from more than 6tha- 1 to complete failure of yields. The yields that can be obtained here range from 4.5 to 6.5tha- 1 Wang et al. [5]. For the tropics, the aerobic rice system is still under development. Martin et al. 2007 reported that upland rice variety PMK 3 produced the highest grain yield of $3684 \mathrm{kgha}-$ 1 and it was significantly superior to other rice varieties under aerobic rice cultivation in Coimbatore.

Lalat variety has yielded maximum (3.10tha-1) from treatment N3 (125kg N ha-1) under aerobic condition during kharif season 2010, which was statistically at par with treatment N2 (100kg N ha-1) at Rice Research Station, Bankura, West Bengal, India. The treatment W3 i.e. pre-emergence application of pendimethalin @1.0kgha-1 at 3 DAS + Rice : Dhaincha (1:1) + 2, 4-D Na salt application (@0.80kg ha-1) at 25 DAS (known as brown manuring) has recorded excellent performance and contributed to maximum grain yield of $3.96 \mathrm{t}$ ha-1 and it was statistically at par with treatment W1 [pendimethalin@1.0kgha1 at 3 DAS + Rice : Dhaincha (1:1) + one hand weeding at 60 DAS].

Highest grain yield (4.15 and 4.36tha-1) was recorded from IET-17509 and satisfactory grain yield (2.98 and 3.23t ha-1) was obtained from Annada in aerobic rice system under unpuddled situation from an observational trial, was conducted during rabi season, 2011 at Rice Research Station, Bankura, west Bengal, India Anon [13]. Highest grain yield of aerobic rice during kharif season might be due to application of higher dose of nitrogen, best weed control method and incorporation of dhaincha in soil. Dhaincha act as smoother plant and control the weeds in Rice: Dhaincha (1:1) plots at early growth stage of rice upto 25 DAS.

Dhaincha was incorporated into soil or mulched the soil in between two rice row at 25 DAS and had significant effect on nutrient utilization as well as availability of soil NPK, conserve soil moisture, control weeds and improved organic carbon status of the soil as they decomposed and helped in better growth and development of rice plant and gave higher grain yield Jana [11].

\section{Variable yields in aerobic rice system}

The incidence of very variable yield and complete yield failure were observed in dry season in the Philippines. Low aerobic rice grain yield (1tha-1) was resulted from the experiment, which was conducted during boro season at Rice Research Station, Bankura under red and laterite zone of West Bengal. High atmospheric temperature was prevailed during flowering period, grain formation and grain ripening stages, respectively. 
As a result of which, more number of grain in a panicle became chaffy and ultimately produced low grain yield of aerobic rice.

It was mainly due to floret sterility. Low grain yield of rice in aerobic situation during summer season, 2012 was mainly due to high temperature during flowering period, grain formation and grain ripening stages. Spikelet sterility at high temperature was the main reason for lower grain yield during summer season. It needed too much care and good management practice for raising rice in aerobic situation during summer season Jana et al. [12]. Yield decline or failure is often associated with 'soil sickness'. Possible reasons for decline yields or even failures to grow crops foe the first time in an area could be soil-borne pests and diseases such as fungi, nematodes and root aphids particularly in tropics.

Another reason for yield decline in continuous cropping may results from interwoven factors including build-up of soil-borne pathogens, depletion of mineral nutrients, and accumulation of toxic substances, is called allelopathy as reported by Ventura et al., 1984. Yield decline has also been reported from aerobic rice systems in Barzil Pinheiro et al. [14], where this phenomenon has been attribute to 'autotoxicity'. Other possible reason for declining yields or even complete failures are soil borne pests and diseases. Root knot nematode (Meloidogyne graminicola) is one potential threat in upland rice eco-system and intermittent irrigation system in the Philippines Prot et al. [15]. For crop management practices, the identification of the major cause to limited crop growth is important and then rough division into abiotic and biotic factors [16,17].

\section{Advantages of aerobic rice cultivation system}

a. Saves labour and water.

b. Direct seeding.

c. Saves seeds.

d. Cost effective.

e. Eco-friendly.

f. No need of puddle operation in field.

g. Aerobic condition in soil.

h. N-use efficiency is more.

i. Cost of cultivation is significantly low.

j. Efficient utilization of rain water.

k. Soil structure is maintained and

l. Improves soil health

\section{Conclusion}

Conventional method of rice cultivation requires large quantities of water and is labour intensive. By 2025 water scarcity is predicted to be severe and management of the available water for various purposes will be a challenging situation. Aerobic rice technologies have been developed for production system that is characterized by economic water scarcity [18]. It is essentially to upgrade the existing farmers' practice of direct seeding of rice in rainfed situation with local varieties that fetched very low yields. Aerobic rice cultivation is a sustainable rice production methodology for immediate future to address water scarcity and environmental safety arising due to global warming [19]. Aerobic rice is the rice of the future

\section{References}

1. Barker R, Dawe D, Tuong TP, Bhuiyan SI, Guerra LC (1999) The outlook of water resources in the year 2020: Challenges for research on water management in rice production. Assessment and orientation towards the $21^{\text {st }}$ century, pp. 96-109.

2. Bouman BAM, Tuong TP (2001) Field water management to save water and increase its productivity in irrigated rice. Agricultural Water Management 49 (1): 11-30.

3. Jana K (2012) Aerobic Rice System towards Tackling Climate Change. SATSA Mukhopatra - Annual Technical Issue 16: 81-88.

4. Bouman BAM, Peng S, Castaneda AR, Visperas RM (2005) Yield and water use of irrigated tropical aerobic rice systems. Agricultural Water Management 74(2): 87-105.

5. Wang H, Bouma BAM, Dule Z, Wang C, Moya PF (2002) Aerobic rice in northern China: opportunities and challenges. Water-wise rice production. Proceedings of the International Workshop on water-wise Rice Production, IRRI, Los Banos, Philippines, pp. 143-154.

6. Xiaoguang Y, Bouma BAM, Huaqia W, Zhimin W, Junfang Z, et al. (2005) Performance of temperate aerobic rice under different water regimes in North Chiana. Agricultural Water Management 74(2): 107-122.

7. Maiti D, Banerjee MM (2011) Aerobic Rice-An option for mitigating water scarcity in rice cultivation: SATSA Mukhapatra-Annual Technical Issue 15: 77-83.

8. Hittalmani S (2010) Aerobic method of rice cultivation: Water saving and safe environment. Green farming. Green farming vision 2. 1(5).

9. Mallick GK, Mondal M, Jana K, Ghosh A, Biswas A (2013) Puspa - a new rice variety alternative to Annada, released for upland areas of West Bengal, India. Ecology, Environment \& Conservation 19(4): 1127-1129.

10. Jana K (2013) Evaluation of aerobic rice system during boro season under red and laterite zone of West Bengal. Crop Research An International Journal 45 (1-3): 20-23.

11. Jana $\mathrm{K}$ (2012) Effect of nitrogen levels and weed management practices on grain yield of aerobic rice cultivation system. Green FarmingInternational Journal of Applied Agricultural \& Horticultural Sciences 3 (6): 687-689.

12. Jana K, Mallick GK, Ghosh S (2013) Yield of aerobic rice affected by high temperature stress during summer season - A study from red and laterite zone of West Bengal, India. Journal of Applied and Natural Science 5(2): 394-396.

13. Anonymous (2011) Annual Report: 2010-11, Rice Research Station, Bankura, West Bengal, 26-28 \& 68-71.

14. Pinheiro BS, Castro EMD, Guimaraes CM (2006) Sustainability and profitability of aerobic rice production in Brazil. Field crops Research 97: 34-42.

15. Prot JC, Soriano IR, Matias DM (1994) Major root-parasitic nematodes associated with irrigated rice in the Philippines. Fundamental Applied Nematology 17(1): 75-78. 
16. Development of suitable agro-techniques for aerobic rice in unpuddled situation: Annual Report: 2010-11, Rice Research Station, Bankura, West Bengal, India, pp. 26-28.

17. Martin G, Jammes PPK, Subramanian E (2007) Identification on suitable rice variety adaptability to aerobic irrigation. Journal of Agricultural and Biological Science 2 (2): 1-3.
18. Sing S, Ladha JK, Gupta RK, Bhushan L, Rao AN Weed management in aerobic rice systems under varying establishment methods: RiceWheat Consortium for the Indo-Gangetic Plains, CIMMYT-India and IRRI-India office, NASC complex, New Delhi, India.

19. Vial LK (2007) Alternate-wet-and-Dry (AWD) Rice Systems. A report for Nuffield Australia Project No. RABO 090.

\begin{tabular}{l} 
Your next submission with Juniper Publishers \\
will reach you the below assets \\
- Quality Editorial service \\
- Swift Peer Review \\
- Reprints availability \\
- E-prints Service \\
- Manuscript Podcast for convenient understanding \\
- Global attainment for your research \\
- Manuscript accessibility in different formats \\
( Pdf, E-pub, Full Text, Audio) \\
- Unceasing customer service \\
Track the below URL for one-step submission \\
https://juniperpublishers.com/online-submission.php \\
\hline
\end{tabular}

